\title{
141. C R における骨エッジの検出法の検討
}

\author{
Detection of Bone Egde in Computed Radiography
}

山口労災病院 *山口大学医学部附属病院 **小野田赤十字病院

○岩永秀幸 $*$ 上田克彦 $*$ 大挥昭義 $*$ 西原貞光 霅藤茂治 $* *$ 藤川津義

(H.Iwanaga) (K. Ueda) (A.Ohtuka) (S.Nishihara) (S.Saito) (T.Fujikawa)

【目的】放射線画像を利用して骨計测を行なう場合，测定の基準点は，医師らの主観で決定さ れる.このため,計测結果に主観的な要素が含まれている可能性がある.

デジタル化した放射線画像において西像処理を行ない骨エッジが検出可能であるかを研究し た.今回は,情報工学系で一般的な 2 次元における 3 種颣の一次微分法を用いて骨エッジの 検出法の比較,検討を行なった。

【使用機器】

F C R - 1, O 1 (階調 8 Bit)

NEC 社製 P C -9801

使用言話 ボーランド社製 Turboc ver2.0

使用懪境: M S - D O S ver.3.3B

【方法】操作手順をPig.1に示す，今回，使用した蹦休 テ一夕は,椎体，㯃の僋面，小児の股関節の3種類のテ ータです。

ここで,椎体，滕の僋面の入射線量は，スクリーン一 フイルム系の相対感度，200〜300程度と同等し，また， 小児の伇関節では, 相对感度を1000程度とした。

TabIe.1は, 今回好理に用いた 3 程類の3 3 × MATRIX,

9 点における 1 次微分オペレー夕てす。

それをれ， $\mathrm{x}$ 方向を求める才く゚レー夕と，y方向を求 めるオペレータの 2 種類がある。

ここで,差外法とROBRTS法の2種類のオペレータに は、*マークがつけてあるが,これは改良型を示す。

本来,差分法,ROBERTS法では，隣接する值の差を求めて 出力するというものですが,ここでは $1 つ$ 飛ばしの值 の差を求めている。

今回は,生データに直接，画像好理をおこなっている

ため,グリットの格子目がCRのPIXELサイスと干涉し 骨エッジの検出ができなかったので,この様な改良型 オペレータを使用した。

この 3 種類の 1 次微分オペレータを用いて画像処理 をおこなった。

【処理結果】

1)

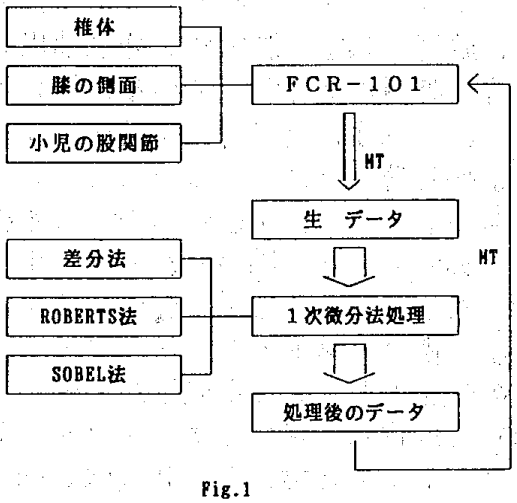

\begin{tabular}{|c|c|c|c|c|c|c|}
\hline & x方向を & める & オイレータ & y方离を水 & 求め & るオヘレータ \\
\hline \multirow{3}{*}{${ }^{*}{ }^{*}$ 差分法 } & 0 & 0 & 0 & 0 & 1 & 0 \\
\hline & 1 & 0 & -1 & 0 & 0 & 0 \\
\hline & 0 & 0 & 0 & $0-$ & -1 & 0 \\
\hline \multirow{3}{*}{${ }^{*}$ RoBERTS法 } & 1 & 0 & 0 & 0 & 0 & 1 \\
\hline & 0 & 0 & 0 & 0 & 0 & 0 \\
\hline & 0 & 0 & -1 & -1 & 0 & 0 \\
\hline \multirow{3}{*}{ SoBrLi法 } & -1 & 0 & 1 & $-1-$ & -2 & -1 \\
\hline & -2 & 0 & 2 & 0 & 0 & 0 \\
\hline & -1 & 0 & 1 & 1 & 2 & 1 \\
\hline
\end{tabular}

*:政良犁
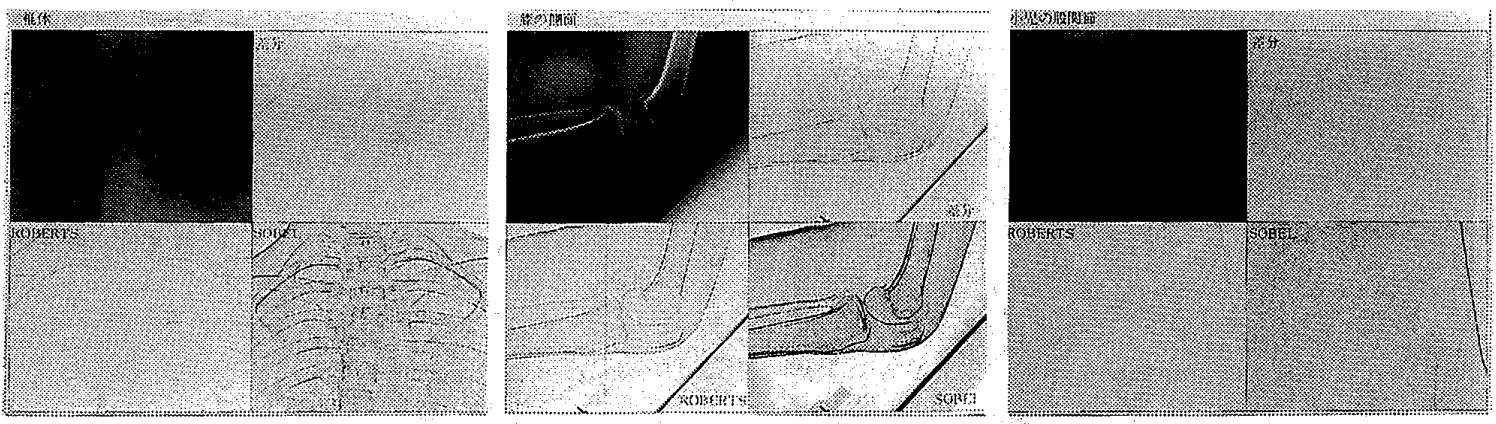

【まとめ】椎体，㯲の侧面，小児の股関節について骨エッジの㭘出効来は,SOBEL法, ROBERTS法 ，差分法の湎でよかつた。しかし，小罗の股阅節の場合では，低線量，低コントラストの画像の ため，鱼エッジの検出ができなかった。

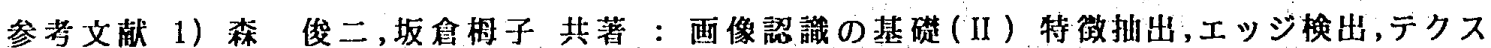
チャ一解析 (オーム社) 